\title{
RESISTENSI ATAS DISKURSUS PLURALISME AGAMA DALAM TEKS MEDIA
}

\author{
Muhamad Isnaini dan Umaimah Wahid \\ Program Studi Magister Ilmu Komunikasi Universitas Mercu Buana, Jakarta \\ Sekolah Pasca Sarjana Universitas Sahid, Jakarta
}

\begin{abstract}
ABSTRAK. Uji materi UU Pencegahan Penodaan Agama (UU No.1/PNPS/1965) telah berlangsung selama Januari-April 2010 lalu. Bermacam diskursus muncul selama uji materi tersebut. Uji materi juga tak luput dari pemberitaan media, termasuk media online. Bagaimana media online dengan ideologi Islam menyikapi diskursus pluralisme agama yang muncul selama uji materi adalah permasalahan utama penelitian ini. Tiga media online dipilih sebagai objek penelitian, yakni Eramuslim.com, Hidayatullah.com, dan Republika online. Penelitian menggunakan pendekatan analisis wacana kritis model Norman Fairclough. Hasil penelitian menunjukkan bahwa media online cenderung resisten atas diskursus pluralisme agama. Resistensi di level teks dilakukan melalui tiga isu, yakni kebebasan beragama tanpa batas, pemikiran liberal, dan konspirasi Barat. Analisis di level praktik diskursus mendukung resistensi itu, dan diperkuat dalam level praktik sosiokultural. Resistensi media online membawa konsekuensi tersendiri, yakni menjadikan mereka sebagai aparatus ideologi negara, melegitimasi penguasa, dan ter-hegemoni kebijakan kekuasaan. Kedepannya, dalam memberitakan isu-isu sensitif (misalnya terorisme, konflik antar umat beragama), media Islam harus mulai berpikir mentarget audience "out of the box". Termasuk mereformasi pilihan tema dan angle liputan. Sesuatu yang lebih "ramah lingkungan" dan tak didominasi rasa "hate speech" terhadap yang lain.
\end{abstract}

Kata kunci: Media online, ideologi, resistensi, legitimasi, hegemoni.

\section{THE RESISTENCE OF RELIGION'S PLURALISM DISCOURSE IN TEXT MEDIA}

ABSTRACT. The review of Religion Blasphemy Prevention Act (UU No.1/PNPS/1965) has lasted from January to April 2010. Various discourse emerged during the review. The review is also not spared from the news media, including online media. The main problem of this research is how online media with Islamic and non Islamic ideology deals with religious pluralism discourse which emerged during the review. Three online media selected as the object of research, namely Eramuslim.com, Hidayatullah.com and Republika online. The research uses Norman Fairclough model of critical discourse analysis as the approach. The research shows that the online media tend to put resistant over religious pluralism discourse. Resistance at the level of text is achieved through three issues, which are religious freedom without limits, liberal thought, and a 
Western conspiracy. Analysis at the level of discourse practice supports that resistance, and strengthened at the level of sociocultural practice. The resistance of online media brings its own consequences, which makes them the state ideology apparatus, legitimate the ruler, and hegemonized by the power policy. For the future, Islamic media should start targeting the audience "out of the box" when preaching sensitive issues (e.g. terrorism, sectarian conflict). Islamic media should also reform the selection of themes and coverage angle. Something more "environmentally friendly" and not dominated by the sense of "hate speech" against another.

Keywords: Online media, ideology, resistance, legitimacy, hegemony

\section{PENDAHULUAN}

Dalam satu dekade terakhir, pluralisme agama menjadi wacana paling mutakhir dan hangat diperdebatkan di kalangan muslim. Konferensi Tingkat Tinggi Organisasi Konferensi Islam (KTT OKI) di Dakar, Senegal, 13-14 Maret 2008 juga menjadikan pluralisme sebagai topik utama. Organisasi yang menghimpun 57 negara Islam itu mengangkat tema tersebut sebagai upaya menghapus ketakutan terhadap Islam yang terus meningkat

Pluralisme agama di kalangan Islam sendiri menimbulkan pro dan kontra, penerimaan di satu sisi dan resistensi di sisi lain. Para pendukung pluralisme agama berpendapat, ide tersebut adalah sebuah keniscayaan di tengah kondisi Indonesia yang majemuk dukungan utama pluralisme agama datang mantan Presiden Abdurrahman Wahid (alm), mantan ketua Pimpinan Pusat Muhammadiyah, Ahmad Syafi'i Maarif, serta para pemikir Islam liberal.

Para penentang pluralisme agama berpandangan bahwa ide tersebut menyesatkan, karena cenderung mencampuradukan ajaran agama dan menganggap semua agama benar. Puncak penentangan atas paham pluralisme agama adalah dengan keluarnya fatwa Majelis Ulama Indonesia (MUI) No. 7/Munas VII/MUI/II/2005 tentang haramnya paham pluralisme, sekularisme, dan liberalisme agama. Rumusan fatwa haram pluralisme agama itu adalah sebagai berikut:

"Pluralisme agama adalah suatu paham yang mengajarkan bahwa semua agama adalah sama dan karenanya kebenaran setiap agama itu adalah relatif; oleh sebab itu, setiap pemeluk agama tidak boleh mengklaim bahwa hanya agamanya saja yang benar sedangkan agama yang lain salah. Pluralisme agama juga mengajarkan bahwa semua pemeluk agama akan masuk dan hidup berdampingan di surga." 
Perdebatan, pro dan kontra, penerimaan dan penolakan atas pluralisme agama yang paling mengemuka adalah saat berlangsungnya uji materi atas Undang-undang No. 1/PNPS/1965 tentang Pencegahan Penyalahgunaan dan atau Penodaan Agama.

Uji materi itu sendiri diprakarsai oleh kalangan penyokong pluralisme agama, misalnya Alm. Abdurrahman Wahid, Dawam Rahardjo, Musdah Mulia, beberapa LSM, misalnya Imparsial, Elsam, PBHI, Demos, Perkumpulan Masyarakat Setara, Desantara Foundation, dan YLBHI. Di sisi lain, pihak yang menolak uji materi UU itu sebagian besar berasal dari kalangan organisasi massa Islam, di antaranya NU, Muhammadiyah, Dewan Dakwah Islamiyah Indonesia (DDII) dan lainnya.

Perdebatan, perlawanan serta penolakan atas diskursus plularisme agama pada akhirnya menular juga ke media. Di antara media yang menolak, situs Eramuslim.com misalnya, menulis bahwa uji materi tersebut merupakan "usaha yang akan mencabikcabik kemuliaan dan kemurnian Islam. Termasuk usaha untuk mengembangkan paham Sekularisme, Liberalisme dan Pluralisme bahkan Atheis (Sepilis A) di antaranya melalui tuntutan pencabutan UU Nomor 1 PNPS Tahun 1965 yang menginginkan liberalisme agama tanpa batas."

Bahkan, situs Hidayatullah.com dengan gamblang mengatakan bahwa Indonesia tidak memerlukan pluralisme. Menurut situs tersebut "pluralisme di Indonesia saat ini bukan lagi sekedar wacana tapi telah merangsek menjadi gerakan aksi. Lebih dari itu pengasong paham pluralisme di Indonesia nampak begitu bersemangat untuk mewujudkan konstruk sosial yang mereka khayalkan."

Media punya peran besar dalam perdebatan mengenai pluralisme agama. Hal ini sejalan dengan apa yang dikatakan oleh Tuchman (dalam Ishadi, 2002) bahwa kegiatan membuat berita telah menjadi kegiatan 'mengkonstruksi realitas' ketimbang sekadar menggambarkan sebuah realitas.

Pemberitaan media terkait isu sensitif seperti pluralisme agama memang menarik dikaji. Gairah para peneliti untuk mengkaji isu juga cukup tinggi. Hal itu terbukti dengan semakin banyaknya skripsi, tesis, disertasi, atau artikel penelitian yang dimuat di berbagai jurnal.

Untuk tulisan ini, studi terdahulu yang menjadi pijakan adalah tesis Husnan Nurjuman (2006) dengan tesis berjudul "Konstruksi Media Islam Indonesia Tentang Pluralisme dalam Islam: Analisis Terhadap Bingkai Majalah Sabili dan Syir'ah tentang Pluralisme dalam Islam di Indonesia". Dengan menggunakan analisis framing William A. Gamson, Husnan meneliti konstruksi realitas 2 majalah Islam, yakni Sabili dan Syir'ah mengenai pluralisme agama. Walaupun kedua majalah itu mengusung tematema Islam, namun dari sisi kesejarahan dan tujuan pemberitaan, keduanya jauh berbeda. Sabili didirikan pasca tragedi Tanjung Priok atau pada masa di mana Orde Baru masih sangat kuat dan meminggirkan Islam. Tak heran bila dalam setiap edisi penebitannya, napas perjuangan Islam begitu kentara. Di sisi lain, majalah Syir'ah 
didirikan setelah Orde Baru tumbang, tepatnya tahun 2001, di mana politik peminggiran terhadap Islam sudah jauh berkurang. Di bawah naungan Yayasan Desantara, yakni yayasan yang bergerak isu-isu Islam dan kebudayaan, terbitlah majalah Syir'ah yang bertujuan untuk mengkampanyekan toleransi beragama.

Tulisan ini dibuat dengan tujuan untuk mengetahui, menggambarkan (memotret), dan menelisik cara Eramuslim.com, Hidayatullah.com, dan Republika online dalam menyajikan isu yang berkaitan dengan pemahaman pluralisme agama dalam Islam terkait dengan uji materi UU No. 1/1965 tentang Penodaan Agama.

\section{METODE}

Penelitian ini bersifat kualitatif yang bertujuan untuk memberikan cara penggambaran suatu realitas, menjelaskan proses yang terjadi di dalamnya, serta menjelaskan berbagai konteks yang melatarbelakanginya.

Moleong (2010) mensintesiskan penelitian kualitatif sebagai penelitian yang bermaksud untuk memahami fenomena tentang apa yang dialami oleh subjek penelitian, misalnya perilaku, persepsi, motivasi, tindakan, dan lainnya, secara holistik dan dengan cara deskripsi dalam bentuk kata-kata dan bahasa, pada suatu konteks khusus yang alamiah dan dengan memanfaatkan berbagai metode ilmiah.

Metode penelitian yang digunakan dalam studi ini adalah analisis wacana kritis. Dengan analisis wacana kritis, maka kita dapat membongkar segala hal (ideologi, kekuasaan) yang tersembunyi di balik teks, Dengan analisis wacana kritis, niscaya akan diketahui bagaimana melalui bahasa (teks berita), tindakan, konteks, kesejarahan, dan kekuasaan yang dimiliki Eramuslim.com, Hidayatullah.com dan Republika Online membentuk diskursus pluralisme agama.

Penelitian ini menggunakan analisis wacana kritis karena pada dasarnya, seperti dikemukakan Eriyanto (2001), berita bukanlah sesuatu yang netral yang memberitakan kelompok yang terlibat apa adanya, karena dalam kenyataannya, berita lebih banyak menyuarakan kelompok yang tidak dominan.

Argumen yang menyokong pendapat tersebut di antaranya, karena realitas pada dasarnya bukanlah sesuatu yang ada dengan sendirinya, tetapi ia dibentuk oleh konstruksi sosial. Dalam proses pembentukan konstruksi semacam ini, terjadi perebutan dan pertarungan pemaknaan.

Unit analisis penelitian ini terdiri atas berita (teks), yang dipakai oleh masingmasing media sampel tatkala media tersebut memberitakan kasus-kasus yang terkait pluralisme agama. Kedua, organisasi situs (portal) berita tersebut.

Analisis berita (teks) yang dilakukan meliputi: bentuk tema/judul berita media sampel dan teks-teks isi berita yang dikumpulkan selama tahun 2010 . 
Teks berita yang dipilih adalah yang mengandung nilai pluralisme agama yang tinggi, yakni kasus uji materi UU No. 1/PNPS/1965 tentang pencegahan penyalahgunaan dan atau penodaan agama.

Metode analisis data yang digunakan dalam penelitian ini adalah metode analisis wacana kritis yang dikembangkan oleh Norman Fairclough. Fairclough membagi analisis wacana dalam 3 dimensi: teks, praktik diskursus, dan praktik sosio-kultural (Eriyanto, 2001). Dalam model Fairclough, teks dianalisis secara linguistik, dengan melihat kosa kata, semantik, dan tata kalimat. Fairclough juga memasukan koherensi dan kohesivitas, bagaimana antar kata atau kalimat digabung sehingga membuat sebuah pengertian. Praktik diskursus, menurut Jorgensen dan Philips (2007), melibatkan pemroduksian dan pengonsumsian teks, sementara praktik sosio-kultural mencakup peristiwa komunikatif (praktik sosial).

Dimensi teks merupakan analisis di tingkat mikro, di mana teks-teks situs berita Islam akan dianalisis secara lingustik. Dalam penelitian ini, seperti telah dibahas sebelumnya, teks yang dianalisis adalah teks berita dengan kandungan pluralisme agama yang tinggi, yakni uji materi UU Penodaan Agama tahun 1965.

Praktik-praktik diskursus, yang merupakan analisis di tingkat meso, terkait dengan proses produksi dan konsumsi teks. Dalam penelitian ini, teks situs berita Islam diasumsikan mempunyai proses produksi yang berbeda, karena dibuat oleh situs Islam yang berbeda, dan berbeda pula dalam hal pola, budaya, sistem kerja, dan yang lainnya. Begitu pula proses konsumsi teks, tentu juga berbeda karena dikonsumsi pada kondisi dan waktu yang berbeda.

Dimensi praktik sosio-kultural berhubungan dengan konteks di luar teks. Misalnya kondisi sosial-ekonomi, politik, dan budaya yang berada di luar organisasi situs berita yang menjadi sampel.

\section{HASIL DAN PEMBAHASAN}

Secara keseluruhan, jumlah teks berita uji materi UU Penodaan Agama di media online sampel yang diteliti berjumlah 109 buah, terdiri atas 6 buah berita Eramuslim.com, 41 berita Hidayatullah.com, dan 62 berita Republika.co.id. Beritaberita tersebut telah diterbitkan selama periode Januari-April 2010.

Teks-teks tersebut kemudian dianalisis untuk melihat bagaimana suatu peristiwa, orang, kelompok, situasi, keadaan atau apapun ditampilkan dan digambarkan.

Berdasarkan variasi judul dan pilihan tema ke-109 berita yang dimuat Eramuslim.com, Hidayatullah.com, dan Republika online tersebut, dapat dilihat suatu kecenderungan pola teks pemberitaan, yaitu:

1. Pada masa awal-awal sidang uji materi UU Penodaan Agama, bentuk judul dan pilihan tema berita media online masih seragam, yakni soal penolakan atas uji 
materi UU tersebut dengan porsi yang dominan, serta secuil berita dari mereka yang mendukung uji materi.

2. Selanjutnya, sesuai dengan perkembangan di arena persidangan, pemberitaan media online mulai mengarah pada kebijakan seleksi isu atau framing bahwa yang menjadi aktor utama di balik uji materi tersebut adalah kehadiran kelompok liberal dengan ide pluralisme agamanya. Dalam mengkonstruksi realitas uji materi dan kelompok liberal itu, media online mulai melakukan strategi 'resistensi' atau perlawanan dengan penonjolan isi berita atau teks yang mendukung strategi resistensi tersebut.

3. Pada akhir masa persidangan, sejalan dengan keputusan MK yang menolak uji materi UU tersebut, di samping mengekspos secara besar-besaran keputusan itu, media online juga mengingatkan masyarakat, lewat pemberitaannya, bahwa pendukung uji materi akan terus berupaya agar UU tersebut direvisi bahkan dihapuskan.

Berdasarkan kecenderungan teks berita dan analisis yang telah dibuat, maka teks berita media online yang ditayangkan selama periode Januari-April 2010 atau ketika uji materi UU Penodaan Agama berlangsung secara umum menampilkan strategi 'resistensi'.

Resistensi oleh media online yang menjadi objek penelitian ini dilakukan untuk mempertahankan eksistensinya ketika mereka tidak nyaman dengan budaya dan pemikiran yang bernama pluralisme, yang lahir dari rahim pos-modernisme dan terang-terangan mengklaim bahwa kebenaran itu relatif sifatnya.

Strategi resistensi yang muncul dalam teks berita media online saat berlangsungnya uji materi UU Penodaan Agama berbentuk penggambaran tandingan atas diskursus pluralisme agama melalui tiga isu, yaitu: (1) Kebebasan beragama tanpa batas (2) Pemikiran liberal, dan (3) Konspirasi global (Barat).

Resistensi media atas pluralisme agama dengan isu kebebasan beragama tanpa batas dapat dilihat dari bentuk representasi teks berita yang diproduksi selama berlangsungnya uji materi UU Penodaan Agama. Contohnya tergambar dari teks berita berikut:

\section{MUI: Pemerintah Wajib Jaga Eksistensi Umat}

JAKARTA--Ketua MUI Jawa Barat KH Hafidz Usman menegaskan bahwa pemerintah wajib menjaga eksistensi umat untuk beribadah sesuai dengan kidah agamanya masing-masing. "Pemerintah sebagai penyelenggara negara juga perlu menegaskan kewenangannya dalam menjamin kemerdekaan penduduk untuk memeluk agama. Untuk itulah diperlukan UU no 1/PNPS/1965 ini," tandas Kiai Hafidz yang diajukan sebagai ahli dari pemerintah dalam sidang MK di Gedung MK jakarta, Rabu (3/3). 
Diungkapkan Kiai Hafidz bahwa dalam perjalanan sejarah bangsa Indonesia, walaupun terdiri dari berbagai suku dan agama, tidak pernah terjadi yang namanya konflik antaragama. "Kalaupun ada konflik, itu bukan konflik karena agama, namun disebabkan pada kepentingan. Artinya UU ini sudah terbukti mampu mengawal kerukunan umat beragama di negeri ini," tandas Hafidz yang juga Ketua Forum Kerukunan Umat beragama (FKUB) Jawa Barat.

Ditegaskannya pula bahwa kebebasan yang sekarang selalu didengungdengungkan dan diekspos sebagai hak asasi manusia, sebenarnya juga sudah termuat dalam UUD 1945, pasal 28 J. "Pada pasal 29 ayat 2 juga memberi jaminan atas mereka yang katakanlah beragama Sinto, taoisme dan agama lainnya di luar enam yang jamak dianut masyarakat kita. Asalkan mereka tidak melanggar," tegas kiai Hafidz.

(Republika Online, Rubrik Islam Nusantara, 3 Maret 2010)

Teks berita di atas dengan tegas menjelaskan bahwa di Indonesia ada kebebasan beragama, bukan hanya agama resmi dan diakui negara, tetapi juga agama lainnya, seperti Shinto dan Tao. Begitu juga dengan kebebasan untuk menjalankan ibadah agama masing-masing, yang dijamin pemerintah untuk menjamin eksistensi masingmasing umat. Namun, kebebasan beragama itu diberi rambu-rambu, di mana dalam berita di atas termuat dalam kalimat "Asalkan mereka tidak melanggar."

Judul berita ini pun tegas, bahwa pemerintah berkewajiban menjaga eksistensi umat, tak terkecuali Islam yang jadi mayoritas, tetapi juga umat beragama lainnya.

Cara penyajian wacana kebebasan beragama ada batasnya dalam berita di atas dapat dilihat dari bagaimana para pendukung uji materi UU Penodaan Agama direpresentasikan dalam teks. Pertama, para pendukung tersebut pada akhirnya akan berhadapan dengan pemerintah. Kedua, para pendukung dilabeli sebagai pihak yang tidak tahu konstitusi karena sebenarnya kebebasan telah diatur dalam UUD 1945, pasal $28 \mathrm{~J}$. Artinya, memang uji materi tersebut tidak perlu diajukan.

Wacana di atas juga dapat dilihat dari relasi yang dibangun dalam teks. Teks berita ini menyertakan 3 pihak yang paling berhubungan, yakni pemerintah, umat, dan MUI, yang diwakili oleh nara sumber tunggal, yakni KH Hafidz Usman, tanpa menyertakan pihak pendukung.

Masih berkaitan dengan relasi adalah identitas pihak-pihak yang diberitakan dalam teks. Teks tersebut meletakkan pembaca pada posisi masyarakat, yang dalam hal ini adalah umat. Para pendukung uji materi diletakkan sebagai musuh 2 pihak sekaligus, yakni musuh umat sekaligus musuh pemerintah.

Resistensi melalui isu pemikiran liberal dapat ditemui dalam teks berikut: 


\section{Jika Gus Dur Hidup, Pasti Tolak Pencabutan UU Penodaan Agama}

Hidayatullah.com -Meski Gus Dur dikenal liberal, andaikan ia masih hidup, pasti menolak pencabutan UU Penodaan Agama no 1/PNPS/1965.

Pernyataan ini disampaikan Ketua Majelis Ulama Indonesia (MUI) Jawa Timur $\mathrm{KH}$. Abdussomad Buchori di sela-sela pertemuan ormas se-Jawa Timur (17/2) di kantor MUI Jl. Dharmahusada Selatan, Surabaya.

Menurut Somad, meski di satu sisi Gus Dur kontroversial, di sisi lain sebenarnya Gus Dur tidak setuju akan hal itu. Hal ini didasarkan pada pertemuannya dengan Gus Dur saat berkunjung ke Rembang, di kala ia masih hidup.

"Kalau untuk masalah politik ikuti saya, namun jika masalah agama, ikutilah KH. Hasim Asyari," ujar Gus Dur ditirukan Somad. "Karena itu, seandainya dia tahu, bisa jadi dia mendukung kita," ujarnya.

Somad menduga, desakan adanya permohonan pencabutan UU Penodaan Agama tidak lain agar Indonesia menjadi negara liberal. Bebas melakukan apapun, termasuk menghujat agama. Dan hal itu, adalah tujuan dari orang pengusung sekularisme, liberalisme, dan pluralisme. Salah satu cara yang ditempuh adalah mencabut UU tersebut.

Adanya tugas berat seperti itu, diakuinya hanya menyibukkan umat Islam. Padahal, tugas umat Islam tidak hanya ngeramu UU penodaan agama, melainkan ekonomi, pendidikan, dan sebagainya. "Tapi, lagi-lagi, orang liberal tidak akan berhenti membuat umat Islam sibuk."

"Sampai kapan pun, dia (liberal, red) akan mengutak-atik aqidah dan shalat, agar kita menjadi sibuk," pungkasnya.

(Hidayatullah.com, Rubrik Nasional, 18 Februari 2010)

Teks berita di atas amat menarik dan provokatif. Dengan memberi judul "Jika Gus Dur Hidup, Pasti Tolak Pencabutan UU Penodaan Agama" teks berita di atas seolah ingin mengadakan 'psy war' pada kelompok liberal dan pendukung uji materi. Padahal, Gus Dur sesungguhnya adalah maskot kelompok liberal dan pluralis serta salah seorang pengusul uji materi tersebut.

Gus Dur adalah orang yang memiliki kharisma tinggi. Ia juga dikenal sebagai sosok yang penuh kontroversi. Dengan mencantumkan nama Gus Dur berulang-ulang di isi berita, media online ingin menegaskan bahwa kontestasi yang sedang berlangsung dengan kalangan liberal terkait dengan masalah-masalah agama justru akan dimenangkan kelompok penentang uji materi. Hal itu diperkuat dalam kalimat : 
"Kalau untuk masalah politik ikuti saya, namun jika masalah agama, ikutilah $\mathrm{KH}$. Hasim Asyari," ujar Gus Dur ditirukan Somad. "Karena itu, seandainya dia tahu, bisa jadi dia mendukung kita,".

Teks berita di atas sangat jelas sekali resistensinya atas kelompok liberal, yang direpresentasikan sebagai "kelompok yang gemar mengutak-atik akidah dan sholat agar umat Islam menjadi sibuk sehingga tidak sempat mengurusi problem umat lainnya seperti ekonomi, pendidikan dan sebagainya."

Konstruksi realitas berita di atas memberi citra negatif pada kelompok liberal, sekular, dan penganjur pluralisme karena akan membawa Indonesia menjadi negara yang bebas, bahkan dengan menghujat agama sekalipun.

Resistensi atas pemikiran liberal juga tercermin dalam teks Eramuslim.com berikut ini:

\section{Lutfi as-Syaukani Menolak Islam dan Nabi Muhammad}

Jumat, 19/02/2010 07:56 WIB

Hari Rabu (17/2) ruang sidang MK dikejutkan dengan pernyataan saksi ahli yang dihadirkan oleh pemohon uji materi UU 1/PNPS/1965, Lutfi as-Syaukani yang menyatakan, bahwa kesalahan Lia Eden, sama dengan kesalahan Nabi Muhammad saat awal kemunculan Islam (detik.com, 17/2/2010).

Pernyataan ini, sebenarnya tidak mengejutkan, jika kita membaca naskah permohonan uji materi UU 1/PNPS/1965 yang diajukan oleh tim advokasi kebebasan beragama, selaku pemohon, sebagai berikut:

"Jika logika penyimpangan agama ini terus dilanjutkan, maka sesungguhnya masing-masing agama merupakan penyimpangan terhadap yang lainnya. Kristen tentu menyimpang dari Yahudi dalam banyak kasus, misalnya bolehnya memakan daging babi atau tidak khitanan dalam Kristen, sementara Yahudi melarang memakan babi dan mengharuskan khitanan. Islam pasti dalam penyimpangan nyata dari agama Kristen yang menganggap Yesus sebagai Tuhan, sementara Islam hanya menganggap Yesus sebagai Nabi. Jika ditunjuk ke dalam sejarah, maka semua agama sebetulnya muncul sebagai bentuk penyimpangan terhadap doktrin-doktrin agama tradisional sebelumnya." (hal. 21)

Bagi Lutfi, dkk tentu Islam dianggap sebagai agama sempalan dari Kristen dan Yahudi. Karena Nabi Muhammad SAW. yang membawa Islam, maka dengan demikian beliau SAW. pun dianggap sebagai orang yang melakukan penyimpangan. Nah, pada titik ini, beliau SAW. dianggap sama statusnya dengan Lia Eden, yang melakukan penyimpangan terhadap ajaran Islam.

Kesimpulan seperti ini bukan saja ngawur, tetapi menunjukkan kebodohan Lutfi, dkk yang luar biasa. Kalau kita telusuri, kesimpulan ini salah sejak presmis pertama, yang dibangun berdasarkan asumsi yang salah, yang 
menyatakan bahwa Islam adalah agama sempalan dari Kristen dan Yahudi. Pertanyaan sederhananya, apa buktinya bahwa Islam merupakan sempalan dari Kristen dan Yahudi? Jelas tidak ada. Kalaulah pada bagian tertentu ada persamaan, tetapi Islam tetaplah Islam; Kristen tetap Kristen dan Yahudi juga tetap Yahudi. Menyamakan ketiganya, karena sama-sama agama samawi juga tidak tepat. Karena secara faktual, ketiganya juga berbeda.

(Eramuslim.com, Rubrik Berita Nasional, 19 Februari 2010)

Teks di atas mengemas pemikiran liberal dalam hal ini diwakili oleh seorang pionirnya, Luthfi as-Syaukani dengan bahasa yang lugas, bahwa kaum liberal menolak Islam dan Nabi Muhammad. Penolakan itu terwujud lewat pemikiran Luthfi yang menyamakan Nabi Muhammad dengan Lia Eden, dan menganggap kesalahan Lia Eden setara dengan kesalahan nabi pada awal kemunculan Islam. Padahal, Lia Eden adalah orang yang menodai Islam karena menyebarkan aliran sesat bernama Salamullah.

Dengan judul yang lugas, yakni "Luthfi as-Syaukani Menolak Islam dan Nabi Muhammad", sesungguhnya dapat diterka hendak di bawa ke arah mana teks tersebut. Luthfi merupakan representasi dari Islam liberal di Indonesia, yang menjadi salah seorang pionir pendirian Jaringan Islam Liberal. Maka, teks berita tersebut ingin menggambarkan sebuah realitas bahwa Jaringan Islam Liberal berperan atas wacanawacana peminggiran Islam.

Di samping itu, teks berita di atas juga ingin mengkonstruksi realitas yang lain, bahwa Luthfi dan kawan-kawan (kaum liberal) memandang Islam sebagai agama yang menyimpang. Teks berita di atas merepresentasikan pemikiran liberal sebagai "kelompok yang ngawur dan bodoh" karena menganggap Islam sebagai agama sempalan. Walaupun, "ngawur dan bodoh" tersebut tidak hanya terkait anggapan Islam sebagai agama sempalan, tetapi juga untuk hal-hal lain. Misalnya pandangan terhadap aliran menyimpang, dalam kasus ini adalah Lia Eden dengan agama Salamullah-nya. Kalimat di paragraf terakhir teks berita di atas adalah argumen kunci untuk menegasikan pikiran Luthfi.

Resisensi melalui isu konspirasi Barat dapat dijumpai dalam teks berita berikut:

\section{Ahli MUI: JIL Lecehkan umat Islam}

JAKARTA--Jaringan Islam Liberal (JIL) di Indonesia dinilai berbuat dan bekerja untuk kepentingan asing. Selama ini di Indonesia, JIL telah menjelek-jelekkan dan menghina umat Islam secara keseluruhan. Hal itu ditegaskan Amin Djamaludin, Ahli dari Majelis Ulama Indonesia (MUI) pada sidang MK terkait judicial review terhadap UU no 1/PNPS/1965 di Gedung MK, Jakarta, Rabu (3/3). 
"JIL yang salah satu koordinatornya adalah Ulil Absor Abdala, mengatakan bahwa ratusan dari ayat-ayat Alquran adalah salah. Padahal kitab Alquran adalah kitab suci umat Islam. Selain itu juga dikatakannya, orang yag meyakini Alquran sebagai wahyu suci dari Allah SWT adalah keledai semua. Itu artinya dia mengatakan bahwa umat Islam di negeri ini keledai semua," tegas Amin Djamaludin yang juga ketua LPPI.

Pada paparannya di depan sidang, Amin menegaskan bahwa banyak sekali penodaan agama yang dilakukan belakangan ini. "Seperti kasus Lia Aminudin, ajaran Surga Eden, Nabi Mosadeq dan lainnya. Saya kira jika tidak ada UU no 1/PNPS/1965 ini, mereka semua telah dibunuh orang karena telah melakukan penodaan agama," ujar Amin.

Karena ada UU tersebut, mereka bisa segera diamankan oleh aparat kepolisian dan terhindar dari amuk massa. "Mereka masih beruntung. Dapat dibayangkan apa yang terjadi jika tidak ada UU ini," tegas Amin.

(Republika Online, Rubrik Islam Nusantara, 3 Maret 2010)

Dalam teks berita di atas, para pendukung pluralisme agama lewat uji materi UU Penodaan Agama direpresentasikan sebagai "kelompok yang bekerja untuk kepentingan asing". Karena bekerja untuk asing itulah, maka segala tindak-tanduk kalangan liberal semuanya beorientasi untuk menjatuhkan umat Islam. Konstruksi realitas tersebut diperkuat dalam kalimat :

"JIL yang salah satu koordinatornya adalah Ulil Absor Abdala, mengatakan bahwa ratusan dari ayat-ayat Alquran adalah salah. Padahal kitab Alquran adalah kitab suci umat Islam. Selain itu juga dikatakannya, orang yag meyakini Alquran sebagai wahyu suci dari Allah SWT adalah keledai semua. Itu artinya dia mengatakan bahwa umat Islam di negeri ini keledai semua."

Penggambaran realitas seperti teks berita di atas seolah ingin menampilkan kesan bahwa memang pihak asing (Barat) turut 'bermain' dalam masalah-masalah keagamaan yang muncul di Indonesia.

Penelitian ini menggunakan Eramuslim.com, Hidayatullah.com, dan Republika online sebagai media sampel. Ketiga media online itu dengan kompak melakukan perlawanan, tidak saja atas uji materi UU Penodaan Agama, namun juga atas semua hal terkait uji materi itu, mulai dari para pendukung, gerakan yang dikembangkan, serta misi yang diusung. Dapat dipahami bila Eramuslim.com dan Hidayatullah.com melakukan perlawanan atas uji materi, gerakan, serta paham yang mendukungnya. Sebab, kedua media tersebut memang dengan tegas mengusung konsep dan idealisme Islam, secara lebih spesifik, Islam literal. Eramuslim.com misalnya, dilahirkan oleh kalangan muda, yang selain peduli dengan media, juga berlatar belakangan 
gerakan dakwah (tarbiyah). Sementara Hidayatullah.com jelas-jelas disokong oleh kekuatan ormas Islam Hidayatullah yang bercita-cita membangun peradaban Islam.

Sikap yang hampir sama diperlihatkan oleh Republika online. Memang, saat ini pemilik saham mayoritas adalah Mahaka Media yang digawangi Erick Tohir, namun akar historis media ini yang sangat kental dengan perjuangan Islam tak lantas membuang warna Islam dari karakteristik medianya. Meskipun Republika online tak tegas menyebut diri sebagai media Islam, tetapi dengan menyebut media umum bernapaskan Islam, sedikit banyak dapat dibaca ke mana arah pemberitaannya. Walaupun harus diakui, pasar media, dalam hal ini umat Islam, menjadi sasaran tersendiri bagi Republika online, yang muaranya adalah kapital.

Di level teks yang mikro, penelitian ini menemukan bahwa teks media online melakukan strategi resistensi atas diskursus pluralisme agama. Strategi resistensi itu menimbulkan kesan positif bagi kelompok yang diwakilinya, namun menciptakan pandangan negatif bagi kelompok yang lain. Tentu, dengan menyebut bahwa pluralisme agama sebagai 'kebebasan beragama tanpa batas', 'buah pemikiran liberal' dan 'konspirasi Barat' adalah upaya media online membangun kedekatan dengan pembacanya.

Teks media online yang resisten atas diskursus pluralisme agama, bila ditelisik lebih jauh, karena dilevel meso (praktik wacana), juga mendukung reistensi tersebut. Bagaimana produksi teks Eramuslim.com yang sangat kental dengan ideologi Islam, menolak sikap liberalisasi Islam, awak redaksi yang dekat dengan gerakan dakwah, menyokong resistensi tersebut. Hal yang sama juga dilihat dari praktik konsumsi teks Eramuslim.com. Begitu juga dengan Hidayatullah.com. Teks-teks di situs ini diproduksi lewat proses ideologi Islam, gerakan dakwah, yang juga anti liberalisasi pemikiran Islam. Konsumsi teks Hidayatullah.com juga menguatkan dukungan atas resistensi tersebut.

Serupa dengan Eramuslim.com dan Hidayatullah.com adalah Republika online. Meski tidak mengusung platform Islam, namun akar historis Republika online tak bisa dilepaskan gerakan perjuangan Islam. Maka, tak heran bila produksi teksnya juga resisten dengan pluralisme agama. Apalagi, dengan jelas Republika online tak sejalan dengan pemikiran Islam liberal.

Di tingkat praktik sosiokultural yang makro semakin terbaca jelas indiksi resistensi media online atas diskursus pluralisme agama. Di level ini, terjadi perseteruan hebat antara Islam literal-eksklusif dengan kalangan liberal-pluralis. Masing-masing pihak menyebarkan prasangka atas yang lain. Pihak liberal-pluralis menuduh kalangan literal-ekslusif sebagai penghambat kemajuan Islam karena dengan berbagai alasan, sementara kalangan literal-eksklusif menuding Islam liberal-pluralis sebagai musuh dalam selimut, pendangkal akidah dan cap lainnya dengan berbagai argumen. Namun, 
pada akhirnya media online mendukung Islam literal karena latar belakang ideologis dan historis media tersebut.

Uji materi Penodaan Agama memang disokong oleh beberapa LSM penggiat HAM dan individu. Para pendukung itu posisinya berada di luar pemerintah (negara). Namun, respons penolakan atas uji materi tersebut tidak hanya dilakukan oleh umat Islam, tetapi juga oleh negara melalui Menteri Agama dan Menteri Kehakiman dan HAM.

Pada posisi inilah, pilihan media Eramuslim.com, Hidayatullah.com, dan Republika online melakukan strategi resistensi atas uji materi tersebut berada dalam posisi dilematis. Sebab, dalam banyak kasus media Islam (yang tentunya berideologi Islam) atau dengan akar historis Islam selalu berada dalam posisi berseberangan (oposisi) dengan kebijakan negara. Namun untuk kasus uji materi ini, ternyata mereka berjalan seiring dengan negara (kekuasaan). Tentu saja hal tersebut sedikit banyak menguatkan tesis yang dikemukakan oleh Althuser bahwa media telah menjadi aparatus ideologi negara/ideological state apparatus (Littlejohn: 2008, Macdonell: 2005, Jones: 2009, Eriyanto: 2001)

Bukan hanya sebagai aparatus ideologi negara yang melegitimasi kekuasaan, strategi resistensi media online atas diskursus pluralisme agama juga membawa konsekuensi lain, yakni media online melakukan fungsi hegemoni. Menurut Gramsci, konsep hegemoni dipakai untuk menjelaskan proses yang terjadi pada superstruktur yang sebagian memainkan peran menciptakan kesadaran masyarakat. Dalam diskursus pluralisme agama, terjadi pertarungan ideologis antara kelompok dominan dengan kelompok terdominasi dalam masyarakat. Dari sinilah kemudian terjadi hegemoni dan counter-hegemoni. Bagi Eramuslim.com, Hidayatullah.com, dan Republika online, karena pemberitaannya sejalan dengan kebijakan penguasa, maka mereka mencerminkan hegemoni kebijakan penguasa. Ketiga media tersebut terhegemoni oleh setiap sikap dan kebijakan yang diambil penguasa.

\section{SIMPULAN}

Di level teks, ketiga media online melakukan strategi 'resistensi' sekaligus melakukan penggambaran tandingan atas diskursus pluralisme agama. Resistensi dilakukan untuk menjamin eksistensi umat dari gempuran budaya luar bernama pluralisme agama yang berpotensi mendangkalkan akidah.

Di level produksi dan konsumsi teks mendukung strategi resistensi tersebut. Ketiga media online punya akar historis Islam yang kuat. Dua media (Eramuslim.com dan Hidayatullah.com) dengan tegas berideologi Islam literal konservatif, sedangkan Republika online, mesti tidak berideologi Islam, namun pangsa pasar utamanya adalah umat Islam. 
Di level praktik sosiokultural, terjadi perseteruan yang hebat di kalangan internal umat Islam antara faksi literal-eksklusif-konservatif versus faksi liberal-pluralis. Strategi resistensi ketiga media online merupakan salah satu bentuk dukungan atas faksi literal-eksklusif-konservatif dan menolak mentah-mentah pandangan kalangan liberalpluralis.

Dengan menjalankan strategi resistensi, pada akhirnya ketiga media online berada dalam posisi sebagai aparatus ideologi negara (ideological state apparatus). Dengan peran sebagai aparat ideologi negara, ketiga media online juga sekaligus sebagai wahana legitimasi penguasa dan ter-hegemoni oleh kebijakan penguasa.

Dalam memberitakan isu-isu sensitif (terorisme, konflik antar umat beragama), media Islam-meminjam istilah Sirikit Syah (korespondensi pribadi, Mei 2011) harus mulai berpikir mentarget pembaca yang lebih besar dari berbagai golongan. Jangan hanya ditujukan untuk dibaca oleh umat Muslim. Tentu mesti ada perubahan format dan isi. Namun, itu perlu tetap dilakukan agar dikonsumsi oleh khalayak yang lebih luas; termasuk mereformasi pilihan tema dan angle liputan, agar lebih "ramah lingkungan" dan tak didominasi rasa "hate speech" terhadap yang lain.

\section{DAFTAR PUSTAKA}

Eriyanto. 2001. Analisis Wacana: Pengantar Analisis Teks Media, Yogyakarta, LKiS.

Eramuslim.com. Lutfi as-Syaukani Menolak Islam dan Nabi Muhammad. http://www.eramuslim.com. Edisi 19 Februari 2010

Hidayatullah.com. 2010. Jika Gusdur Hidup, Pasti Tolak Pencabutan UU Penodaan Agama. http://www.hidayatullah.com. Edisi 18 Februari 2010

Jorgensen, Marianne W. dan Phillips, Louise J. 2007. Analisis Wacana, Teori dan Metode, Yogyakarta, Pustaka Pelajar.

Littlejohn, Stephen W dan Foss, Karen A, 2008. Theories of Human Communication, Belmont, Thomson Wadsworth.

Macdonell, Diane. 2005. Teori-teori Diskursus, Kematian Strukturalisme dan Kelahiran Posstrukturalisme dari Aliran Althusser hingga Foucault, Jakarta, Penerbit Teraju.

Moleong, Lexy. J. 2010. Metodologi Penelitian Kualitatif, Bandung, Remaja Rosdakarya. 
Nurjuman, Husnan, 2006, Konstruksi Media Islam Indonesia Tentang Pluralisme dalam Islam: Analisis Terhadap Bingkai Majalah Sabili dan Syir'ah tentang Pluralisme dalam Islam di Indonesia, Tesis, Program Pasca Sarjana Ilmu Komunikasi, Fakultas Ilmu Sosial dan Ilmu Politik, Universitas Indonesia.

Republika. 2010. MUI: Pemerintah Wajib Jaga Eksistensi Umat. http://www.republika.com.Edisi 3 Maret 2010

Republika. 2010. Ahli MUI: JIL. Lecehkan Umat Islam. http://www.republika.com. Edisi 3 Maret 2010

SK, Ishadi. 2002, Praktek-praktek Diskursus di Ruang Pemberitaan RCTI, SCTV, Indosiar : Analisis Kritis Proses-proses Produksi Teks Berita Menjelang Berakhirnya Pemerintahan Soeharto (Mei 1998), Disertasi, Program Pasca Sarjana Ilmu Komunikasi, fakultas ilmu Sosial dan Ilmu Politik, Universitas Indonesia.

Syah, Sirikit. 2001. Korespondensi pribadi, Mei 2011 